\title{
The Development of ACh- and GABA-activated Currents in Embryonic Chick Ciliary Ganglion Neurons in the Absence of Innervation in vivo
}

\author{
Kathrin L. Engisch ${ }^{a}$ and Gerald D. Fischbach ${ }^{b}$ \\ Department of Anatomy and Neurobiology, Washington University School of Medicine, St. Louis, Missouri 63110
}

\begin{abstract}
Chemical synaptic transmission in the chick ciliary ganglion is mediated by nicotinic $A C h$ receptors. Ciliary ganglion neurons also express $\mathrm{GABA}_{A}$ receptors, although there is no known source of GABAergic innervation of the ganglion, and the function of GABA receptors on these neurons is not known. We examined whether ACh and GABA receptors on embryonic chick ciliary ganglion neurons are regulated by presynaptic inputs. Whole-cell currents evoked by ACh or GABA in neurons soon after dissociation were taken to estimate the level of functional receptors in intact ganglia.

We destroyed the accessory oculomotor nucleus (AON), the only source of synaptic input to the ganglion, on embryonic day (E) 4 . We determined that $80 \%$ of the operations resulted in the virtual elimination of synaptic contacts in the ganglion, using P65 immunohistochemistry (a synaptic vesicle antigen) and direct ultrastructural examination. Previous experiments have shown that during normal development, ACh-activated currents increase over sevenfold between E6 and E18; GABA-activated currents increase only twofold, in proportion to cell size. We found that $A C h$-activated currents of uninnervated neurons at E14 and E18 were as large as control responses. Furthermore, ACh receptor-like molecules, visualized with monoclonal antibody 35 immunofluorescence, were concentrated in high density clusters on the surface of $E 18$ neurons from AON-ablated embryos. GABAactivated currents were aiso not affected by $A O N$ destruction. We conclude that $A C h$ and GABA receptors are not induced in embryonic chick ciliary ganglion neurons during development by contact with or soluble factors released from AON synaptic terminals.
\end{abstract}

ACh-activated currents examined in acutely dissociated embryonic chick ciliary ganglion neurons increase sevenfold between embryonic day (E) 6 and E18 in two steps (Engisch and Fischbach, 1990; see also Margiotta and Gurantz, 1989). We have previously shown that removal of the embryonic eye at E2 does not prevent the dramatic subsequent increase in $\mathrm{ACh}$ -

\footnotetext{
Received May 21, 1991; revised Oct. 21, 1991; accepted Nov. 8, 1991.

This work was supported by NIH Grant RO1 NS18458 and a grant from the Washington University/Monsanto Biomedical Research Program. We thank Grady Phillips and Dr. Michael Dailey for sharing their electron microscopy expertise.

Correspondence should be addressed to Gerald D. Fischbach, Department of Neurobiology, Harvard Medical School, 220 Longwood Avenue, Boston, MA 02115 .

- Present address: Department of Physiology, University of Maryland School of Medicine, 660 West Redwood Street, Baltimore, MD 21201.

b Present address: Department of Neurobiology, Harvard Medical School, 220 Longwood Avenuc, Boston, MA 02115.

Copyright (C) 1992 Society for Neuroscience $0270-6474 / 92 / 121115-11 \$ 05.00 / 0$
}

activated current. It is possible that the arrival of preganglionic axons and the elaboration of cholinergic terminals within the ganglion induce the expression of functional neurotransmitter receptors on embryonic chick ciliary ganglion neurons - by direct contact or by the release of receptor-inducing factors.

Presynaptic nerve fibers from the accessory oculomotor nucleus (AON) are present in the ganglion as early as E3.5-E4 (Furber et al., 1987; Jacob, 1991); by E8 every neuron in the ganglion can generate an action potential in response to preganglionic nerve stimulation (Landmesser and Pilar, 1972). However, it is not until E15 that specialized contacts between vesicle-filled presynaptic nerve terminals and postsynaptic densities become readily apparent in electron micrographs (de Lorenzo, 1960; Hess, 1965; Landmesser and Pilar, 1972; see also Jacob and Berg, 1983; Jacob et al., 1986; Loring and Zigmond, 1987). ACh sensitivity increases in two stages; it is interesting that the second and larger increase corresponds to the time when ACh receptor binding, defined with ${ }^{125}$ I-Toxin $F$ (Loring and Zigmond, 1987) and HRP-monoclonal antibody 35 (mAb35) (Jacob et al., 1984; Jacob and Berg, 1988) is highly concentrated at synapses. Perhaps the number of $\mathrm{ACh}$ receptors on each neuron increases during development in proportion to the increase in specialized synaptic sites.

Our previous study (Engisch and Fischbach, 1990) provides some evidence against the hypothesis that neural input regulates the level of functional $\mathrm{ACh}$ receptors in developing chick ciliary ganglion neurons. It is known that following early eye removal, there is almost complete cell loss in the AON by E14 (Cowan and Wenger, 1968; see also Narayanan and Narayanan, 1976). This transneuronal degeneration of the AON suggests that, in our earlier study, eye ablation not only removed the target tissues of the embryonic ciliary ganglion but, after E14, deprived the neurons of their innervation as well, yet ACh-activated currents increased threefold between E14 and E18 in these neurons (Engisch and Fischbach, 1990).

To examine more directly whether the initial level or the developmental increase in $\mathrm{ACh}$-activated current of chick ciliary ganglion neurons is due to the presence of preganglionic terminals, we surgically destroyed the AON on E4, $24 \mathrm{hr}$ before synaptic transmission through the ganglion can be detected (Landmesser and Pilar, 1972), shortly after the first presynaptic terminals arrive in the ganglion (Furber et al., 1987; Jacob, 1991). Ciliary ganglion neurons are also sensitive to GABA, and an increase in GABA-activated currents parallels the increase in cell size observed during development (Engisch and Fischbach, 1990). There is no known GABAergic input to the ganglion, so it was of interest to compare the effect of $\mathrm{AON}$ ablation 
on ACh-activated currents with any effects on GABA-activated currents.

\section{Materials and Methods}

AON destruction. AON ablation was performed as described in Furber ct al. (1987). Eggs werc incubated on thcir sides. On E4, the amnion overlying the embryonic head was removed with fine forceps so that the head could be rotated upright and held in place by a glass probe. The optic tectum was split open at the midline with fine forceps, and a battery-operated electrocautery with an angled tip (width, $0.5 \mathrm{~mm}$; Fine Science Tools, Belmont, CA) was inserted at the caudal edge of the opening to a depth of $2 \mathrm{~mm}$, or until it just touched the underlying midbrain. Electric current was applied for about $1 \mathrm{sec}$, during which time a large portion of the midbrain and some hindbrain area turned white; a region larger than the nucleus was destroyed. A few drops of PBS and penicillin $(5000 \mathrm{U} / \mathrm{ml})$ and streptomycin $(5000 \mu \mathrm{g} / \mathrm{ml})$ were released onto the embryo, and the egg was sealed with cellophane tape and returned to the incubator. In sham operations, the amnion was removed, the head rotated, and the tectum split open but the electrocautery probe was not inserted into the opening. Unless otherwise noted, embryos were incubated until E14 or E18.

Cell dissociation. Ganglia were dissociated into a suspension of single cells as previously described (Engisch and Fischbach, 1990). Several ganglia were dissected in PBS, incubated at $37^{\circ} \mathrm{C}$ in $0.05 \%$ trypsin in PBS for $30 \mathrm{~min}$ (E14) or $1 \mathrm{hr}$ (E18), and resuspended in Eagle's minimum essential medium (MEM) containing $1 \mathrm{~mm}$ glutamine, penicillin and streptomycin, and $5 \%(\mathrm{v} / \mathrm{v})$ chick embryo extract. The ganglia were triturated and plated in the same medium. Conditions were not altered for operated ganglia, although these ganglia were encased by less connective tissue than controls. Ganglia from AON-ablated and age-matched or sham-operated embryos were dissociated and plated at the same time in separate dishes on two $12 \mathrm{~mm}$ glass coverslips that contained a layer of embryonic myotubes (Role and Fischbach, 1987). The dissociated ciliary ganglion neurons attached to the cultured myotubes within $3 \mathrm{hr}$ (Engisch and Fischbach, 1990).

Physiology. ACh and GABA sensitivity of control and operated neurons was tested 3-6 hr after plating. The recording solution consisted of Eagle's MEM supplemented with $11 \mathrm{~mm}$ glucose but no glutamine, serum, or embryonic extracts. Bath $\mathrm{pH}$ was maintained at 7.2-7.4 by a continuous flow of a $10 \% \mathrm{CO}_{2} / 90 \% \mathrm{O}_{2}$ mixture over the recording chamber. All experiments were performed at room temperature. Neurons were held at $-50 \mathrm{mV}$ using standard whole-cell patch-clamp recording methods (Hamill et al., 1981). Patch electrodes were fabricated from borosilicate glass $(1.2 \mathrm{~mm}$ o.d., with filament; World Precision Instruments, New Haven, CT) fire polished and filled with intracellular solution (140 mM KCl, $11 \mathrm{~mm}$ EGTA-K, $10 \mathrm{~mm}$ HEPES-K, $2 \mathrm{~mm}$ $\mathrm{MgCl}_{2}$, and $\left.1 \mathrm{mM} \mathrm{CaCl}_{2}, \mathrm{pH} 7.2\right)$. ACh $(250 \mu \mathrm{M})$ or GABA $(100 \mu \mathrm{M})$ dissolved in recording solution was applied for $200-300 \mathrm{msec}$ by pressure ejection ( $5 \mathrm{psi}$ ) from micropipettes positioned $5-10 \mu \mathrm{m}$ from the neuron soma (Choi and Fischbach, 1981; Engisch and Fischbach, 1990). The recording chamber was not continuously perfused, but cells were locally washed by a non-drug-containing puffer pipette between each drug pulse and by bath rinses after each cell recording. Peak currents evoked by ACh and GABA were collected and analyzed as previously described (Engisch and Fischbach, 1990). Capacitance was calculated from the time constant of decay of the current evoked by a $10 \mathrm{mV}$ hyperpolarizing voltage step.

Electron microscopy. Ganglia were fixed overnight in 1\% glutaraldehyde, $1 \%$ formaldehyde, and $5 \%$ sucrose in $0.1 \mathrm{M}$ cacodylate buffer (pH 7.4), stained in $1 \%$ osmium tetroxide, dehydrated in an acetone series, and embedded in propylene oxide and Araldite 502 before ultrastructural examination (Marshall, 1981; Loring et al., 1985). Sections from one control ganglion and five ganglia from AON-ablated embryos were examined.

Synaptic vesicle immunohistochemistry. Ascites fluid containing $\mathrm{mAb}$ P65, a mouse monoclonal antibody raised against bovine P65 synaptic vesicle protein, was a gift of John Bixby (University of California, San Francisco). Ganglia were dissected on E18 in cold PBS with added divalent cations ( $1 \mathrm{mM} \mathrm{CaCl}_{2}, 0.8 \mathrm{mM} \mathrm{MgCl}_{2}$ ), frozen, and serially sectioned on a cryostat at $-20^{\circ} \mathrm{C}$ at $12 \mu \mathrm{m}$ intervals. Representative sections were fixed for $10 \mathrm{~min}$ in $10 \%$ formaldehyde/PBS $/ 5 \%$ sucrose, rinsed in PBS, and then incubated in PBS containing $1 \%$ goat serum and $0.05 \%$ saponin $(\mathrm{P} / \mathrm{G} / \mathrm{S})$ (Bixby and Reichardt, 1985). All antibodies were diluted in $\mathrm{P} / \mathrm{G} / \mathrm{S}$. A 20 min rinse (five times, $4 \mathrm{~min}$ each) in $\mathrm{P} / \mathrm{G} / \mathrm{S}$ separated each antibody incubation. The sections were incubated for 1 $\mathrm{hr}$ in 1:500 mAb P65 at room temperature, followed by a $1 \mathrm{hr}$ incubation in 1:100 goat anti-mouse linker antibody (unconjugated), and a $30 \mathrm{~min}$ incubation in 1:100 mouse peroxidase-antiperoxidase (PAP). Sections were then rinsed in Tris- $\mathrm{HCl}$ buffer $(0.05 \mathrm{M}, \mathrm{pH} 7.5-7.6)$ and incubated in $0.06 \%$ diaminobenzidine (made from aliquots of the dry powder) in Tris buffer containing $0.01 \% \mathrm{H}_{2} \mathrm{O}_{2}$ for 20 min or until reaction product became visible (Lansdorp et al., 1984). Sections were rinsed in PBS followed by water and then air dried before mounting in Citifluor (glycerol/PBS solution). mAb P65 labeling of frozen ciliary ganglia sections was examined with Nikon $20 \times$ and $40 \times$ dry objectives and photographed with Kodacolor 400 ASA film.

ACh receptor immunohistochemistry. Ciliary ganglion ncurons were dissociated and plated on embryonic myotubes on $18 \mathrm{~mm}$ glass coverslips. The protocol for $\mathrm{mAb} 35$ labeling was performed on cultures 4 hr after plating. All antibodies were diluted in Eagle's MEM containing $10 \%$ horse serum (MEM-HS); the cells were rinsed in MEM-HS after every antibody incubation, and in PBS before and after fixation. Cells were incubated for $1 \mathrm{hr}$ at $0^{\circ} \mathrm{C}$ in $1: 100 \mathrm{mAb} 35$ supernatant, fixed at room temperature for $20 \mathrm{~min}$ in $10 \%$ formaldehyde $/ 2.5 \%$ sucrose in PBS, incubated for $1 \mathrm{hr}$ at room temperature in 1:300 fluorescein isothiocyanate (FITC)-goat anti-mouse (with cross-reactivity to rat) and $1 \mathrm{hr}$ at room temperature in a 1:150 dilution of FITC-swine anti-goat. Coverslips were rinsed in PBS and $\mathrm{H}_{2} \mathrm{O}$ and air dried before mounting in Citifluor.

Frozen sections of E18 ganglia were obtained as described for $\mathrm{mAb}$ P65 immunohistochemistry, except the ganglia wcrc scctioned at $16 \mu \mathrm{m}$ intervals. The sections were treated in the same manner as live dissociated cells. Labeled dissociated cells were examined under Nikon fluorescence optics with an oil immersion $100 \times$ objective (NA $=1.4)$ and photographed with Kodak 400 ASA TMAX film. Sections were examined with an oil immersion $40 \times$ objective $(\mathrm{NA}=1.3)$ and photographed with Kodak Ektachrome developed at ASA 1600.

Materials. Fertilized eggs were obtained from Spafas (Roanoke, IL). Goat anti-mouse (unconjugated), GAM-fluorescein isothiocyanate (FITC), Sheep anti-mouse-FITC, and mouse PAP were all purchased from Boehringer-Mannheim (Indianapolis, IN). Culture media components were obtained from GIBCO (Grand Island, NY). ACh chloride, GABA, saponin, and DAB were purchased from Sigma Chemical Co. (St. Louis, MO).

\section{Results}

\section{Gross morphology of operated embryos}

The heads of E18 AON-ablated embryos were distorted compared to age-matched controls. Usually, skin and bone did not cover the brain; instead, a fluid-filled bulb of tissue extended out from the bone cavity. The back of the head was also much reduced in size, appearing flattened compared to normals. Despite the gross damage, $47 \%(105 / 225)$ of the AON-ablated embryos survived to the desired developmental stages. Shamoperated embryos did not show extensive CNS damage, although occasionally the skin did not completely cover the head; $51 \%(20 / 39)$ of these embryos survived to the desired developmental stages.

\section{Ganglionic volume was reduced following AON ablations}

It is known from counts of ciliary ganglion neurons in $7-10 \mu \mathrm{m}$ paraffin sections that therc arc 6000 neurons in E8 ganglia and 3000 in E14 ganglia, after the period of "programmed" cell death (Landmesser and Pilar, 1974; Pilar et al., 1980; Furber et al., 1987). Following AON ablation, only 900 neurons are present in E14 ganglia (Furber et al., 1987). As expected considering the augmented cell death, we found that E1 8 ganglia from AON-ablated embryos (Fig. $1 b$ ) were much smaller than age-malched or sham-operated controls (Fig. 1a). No preganglionic nerve was observed entering any of the operated ganglia, although a thin, translucent nerve might have been missed.

Operations on E4 are not likely to have destroyed precursor 

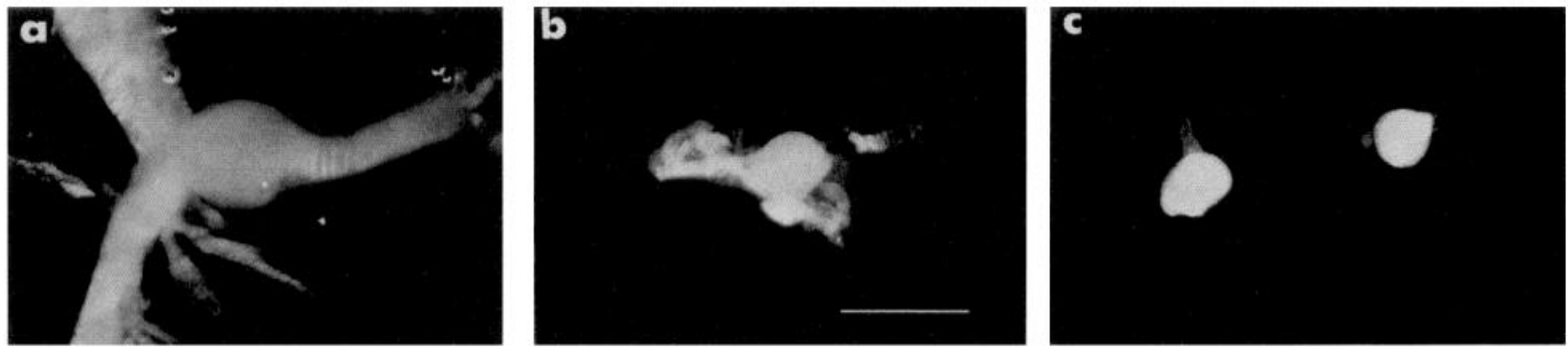

Figure 1. The reduction in ganglionic volume after AON ablation was due to removal of the AON, not to destruction of ganglionic precursor cells. $a$, An E18 ganglion from a control embryo. The oculomotor nerve enters the ganglion at the upper left, and emerges at the lower left. The postganglionic nerve exits the ganglion at the right. The small processes fanning out from the oculomotor nerve as it leaves the ganglion were seen entering the ocular muscles when the ganglion was in situ. $b$, An E18 ganglion from an AON-ablated embryo, showing the dramatic decrease in ganglion size. The connective tissue surrounding the ganglion did not resemble nerve processes in vivo. $c$, E8 ganglia from a control (left) and an AON-ablated (right) embryo. Ganglion volume was not reduced at E8, prior to the cell death period (E9-E14). Scale bar, $1 \mathrm{~mm}$.

cells, all of which should have migrated from the neural crest by this stage (Furber et al., 1987). However, it is possible that the reduction in ganglion volume was due to the direct damage of the ganglion during the operation. Therefore, we examined ganglia at E8, before the period of cell death. E8 ganglia from AON-operated embryos were not noticeably smaller than E8 control ganglia (Fig. 1c). Thus, most of the loss in ganglion volume must have occurred during the cell death period.

\section{ACh-activated currents}

The cells dissociated from AON-ablated embryos were not noticeably smaller than control neurons, were phase bright, and had normal resting membrane potentials $(-50 \mathrm{mV})$. Typical

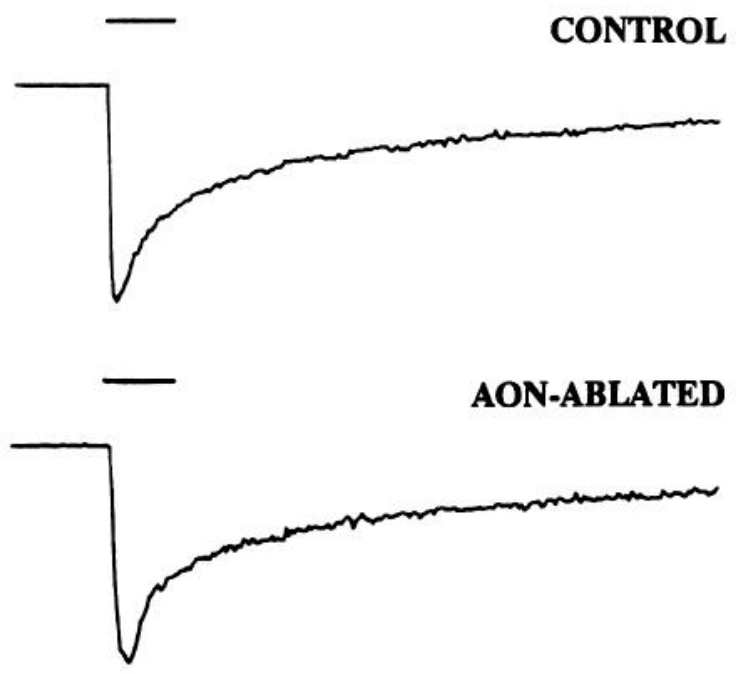

1000pA

500me

Figure 2. AON ablation did not alter the time course of ACh-activated currents. Whole-cell currents were evoked in acutely dissociated neurons held at $-50 \mathrm{mV}$. ACh $(250 \mu \mathrm{M})$ was applied by pressure ejection for $250 \mathrm{msec}$ (indicated by a line over each trace). The ACh-activated current of the uninnervated neuron (following AON ablation; bottom trace) is virtually identical to the current evoked by $\mathrm{ACh}$ in the control neuron (upper trace).
ACh-activated currents from control and AON-deprived neurons are shown in Figure 2. The peak currents of this control and operated neuron were identical. In both neurons, the $\mathrm{ACh}$ current rose to a peak within $100 \mathrm{msec}$ and began to decay before the end of the pressure pulse. This is most likely due to receptor desensitization. The slower decay of the currents after the pulse was terminated probably represents the diffusion of drug away from the cell body. There were no obvious differences between control and operated neurons in rates of activation or desensitization following application of $250 \mu \mathrm{M} \mathrm{ACh}$.

Data from E14 and E18 ganglion neurons are summarized in Figure 3. The mean ACh-activated current of E14 neurons from AON-ablated embryos ( $1291 \pm 117 \mathrm{pA}, N=19$; solid bar) was not different from the mean current of sham-operated, agematched controls within the same experiments $(1483 \pm 124$ $\mathrm{pA}, N=11$; open bar), or from the mean of E14 control data pooled from this and a previous study $(1140 \pm 68 \mathrm{pA}, N=54$;

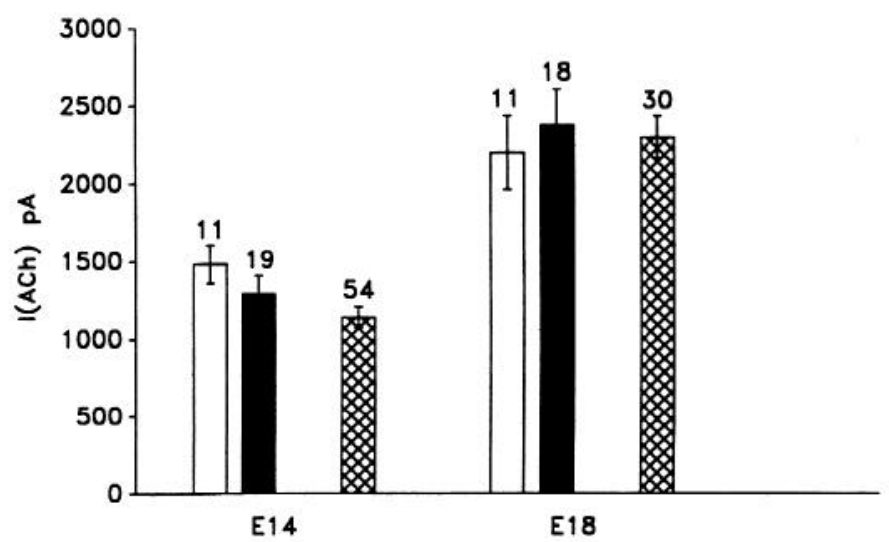

Figure 3. AON ablation did not affect the magnitude of ACh-activated currents. The means of ACh-activated currents from E14 and E18 uninnervated neurons (solid bars; \pm SEM) were not statistically different (Student's two-tailed $t$ test) from those of sham-operated and age-matched control neurons within the same experiments (open bars) or from the means of pooled currents from innervated neurons in this and a previous study (Engisch and Fischbach, 1990; crosshatched bars). The number of neurons assayed are shown above each bar. ACh-activated currents increased almost twofold between E14 and E18 in neurons of ganglia from $\mathrm{AON}$-ablated embryos. The data for $\mathrm{AON}$-ablated ganglia represent cells sampled from three different experiments, in which two, five, and five ganglia were dissociated at E14; and four, five, and five ganglia were dissociated at E18. 

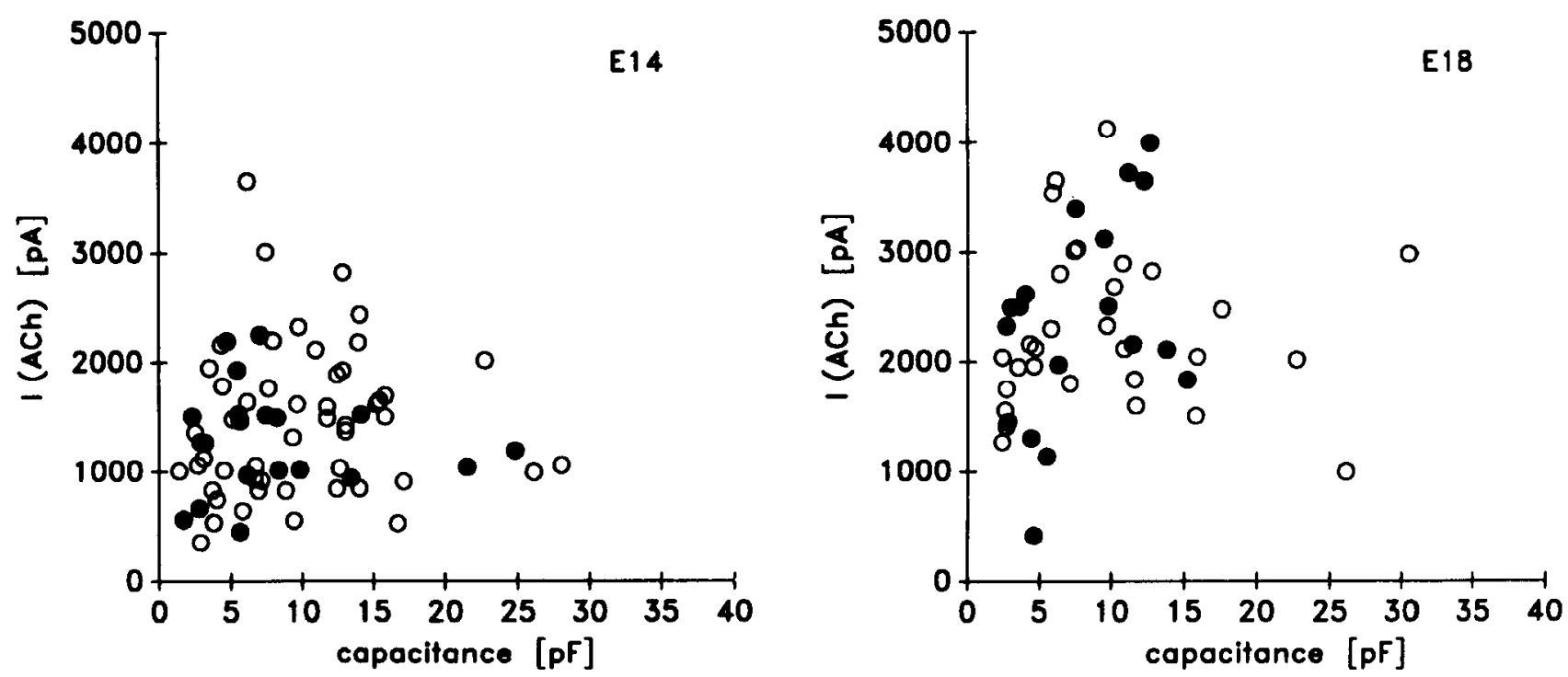

Figure 4. Following AON ablation, the distribution of ACh-activated currents as a function of capacitance was unchanged. At both E14 and E18, responses of uninnervated neurons (solid circles) overlapped responses from all innervated neurons measured to date (open circles).

crosshatched bar) (Student's two-tailed $t$ test). All errors are expressed as SEM. Similarly, the mean ACh-activated current of E18 neurons was not different after AON ablation: $2368 \pm$ $233 \mathrm{pA}, N=18$ (solid bar), compared to a mean current of 2193 $\pm 236 \mathrm{pA}, N=11$, for sham-operated controls (open bar), and $2289 \pm 137 \mathrm{pA}, N=30$, the mean of all E18 responses recorded to date (crosshatched bar) (Student's two-tailed $t$ test). The increase in ACh-activated currents between E14 and E18 that occurred during normal development (Engisch and Fischbach, 1990) was still evident after AON ablation on E4.

As has been noted for innervated neurons (Engisch and Fischbach, 1990), the variation in the magnitude of ACh-activated currents of uninnervated neurons was not explained by variations in cell size. In Figure 4, plots of ACh-activated currents from uninnervated neurons as a function of capacitance (solid circles) completely overlap control responses (open circles) at both E14 and E18. The populations are indistinguishable, except for the absence of the largest cells in the operated population at E18. Despite the apparent loss of the largest cells, mean capacitance of neurons from E18 operated ganglia, $7.8 \pm 1.0 \mathrm{pF}, N$ $=18$, was not significantly reduced compared to the pooled mean capacitance of all controls to date, $9.7 \pm 1.3 \mathrm{pF}, N=30$ (Student's two-tailed $t$ test). Thus, neurons that survive the loss of AON inputs grow as large as innervated ciliary ganglion neurons.

\section{$G A B A$-activated currents}

GABA-activated currents were also not affected by AON destruction (Fig. 5). The mean GABA-activated current of E14 neurons from AON-operated ganglia $(4537 \pm 699 \mathrm{pA}, N=19$; solid bar) was the same as the mean GABA-activated current of sham-operated control neurons within the same experiments (4017 $\pm 765 \mathrm{pA}, N=9$; open bar), and of all control neurons tested to date ( $4506 \pm 402 \mathrm{pA}, N=54$; crosshatched bar). Unlike ACh-activated current, which increased between E14 and E18, GABA-activated current decreased by $25-50 \%$ in operated ( 2346 $\pm 383 \mathrm{pA}, N=12 ; p<0.01$, Student's single-tailed $t$ test), sham-operated ( $2303 \pm 352 \mathrm{pA}, N=11 ; p<0.05)$, and pooled control neurons (3006 $\pm 518 \mathrm{pA}, N=30 ; p<0.025)$.
The distribution of GABA-activated currents from uninnervated neurons as a function of capacitance was similar to the distribution of responses from control neurons (Fig. 6). As previously notcd in normal (innervated) neurons (Engisch and Fischbach, 1990), the variation in GABA-activated currents of neurons from AON-ablated embryos was more closely related to the variation in cell size than were ACh-activated currents at both E14 and E18.

\section{Were insensitive cells missed?}

It is unlikely that the results presented here can be explained by the loss of insensitive, denervated neurons during dissociation of ganglia from AON-ablated embryos, since the percentage cell yields from ganglia of operated embryos were greater than

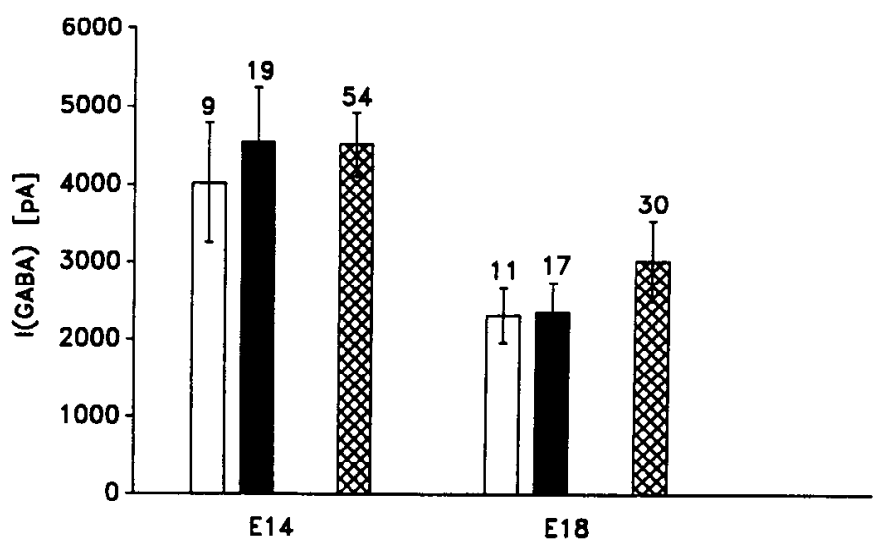

Figure 5. AON ablation did not affect the magnitude of GABA-activated currents. GABA responses were evoked in acutely dissociated neurons (held at $-50 \mathrm{mV}$ ) by pressure ejection of $100 \mu \mathrm{M}$ GABA for $300 \mathrm{msec}$. The means of GABA-activated currents from E14 and E1 8 ciliary ganglion neurons of AON-ablated embryos (solid bars; \pm SEM) were not different from those of neurons from sham-operated or agematched controls within the same experiments (open bars) or from means of currents pooled from all innervatcd ncurons assayed to date (crosshatched bars). The number of neurons sampled is above each bar. 

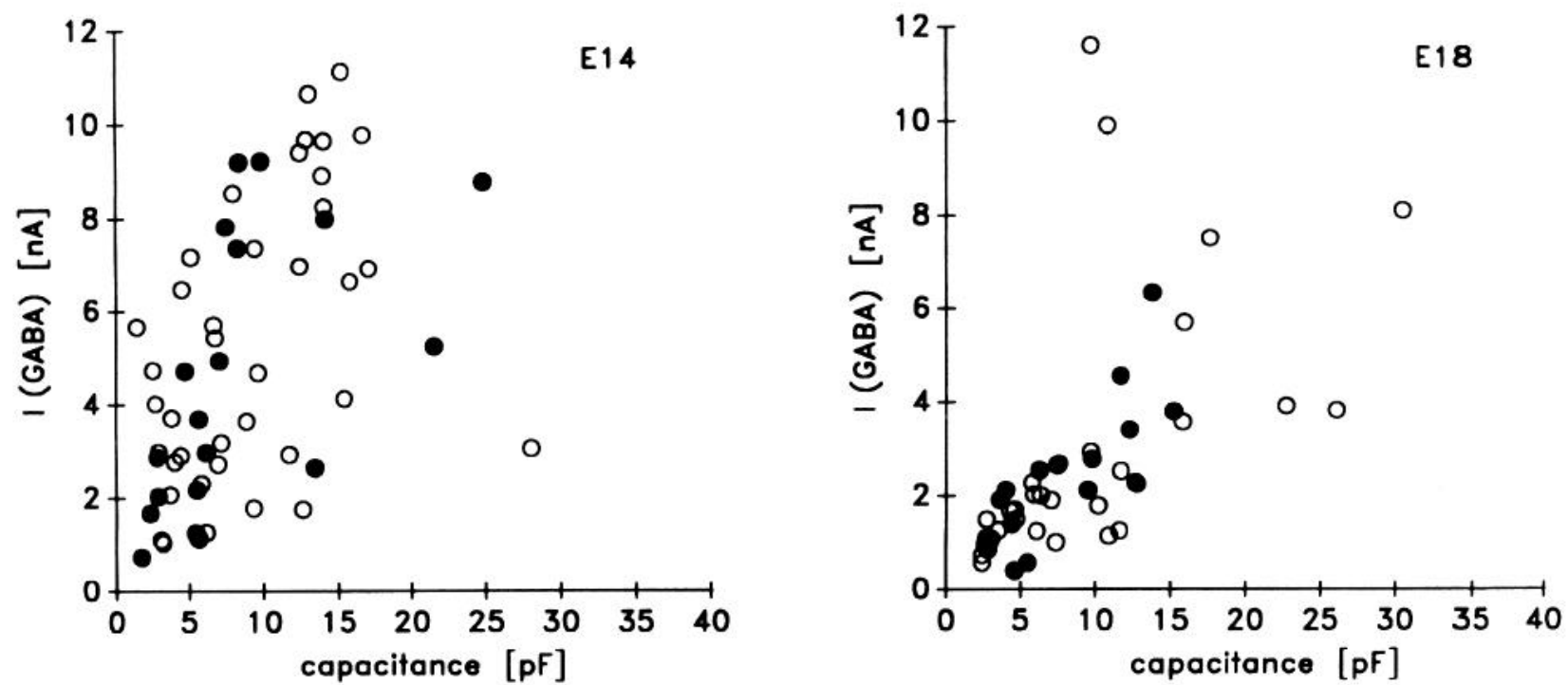

Figure 6. Following AON ablation, the distribution of GABA-activated currents as a function of capacitance was unchanged. At both E14 and E18, GABA responses from uninnervated neurons (solid circles) overlapped responses from all innervated neurons measured to date (open circles). As in innervated neurons, the variation in the magnitude of GABA-activated currents in neurons from AON-ablated embryos is more closely related to capacitance than is the variation in ACh-activated currents.
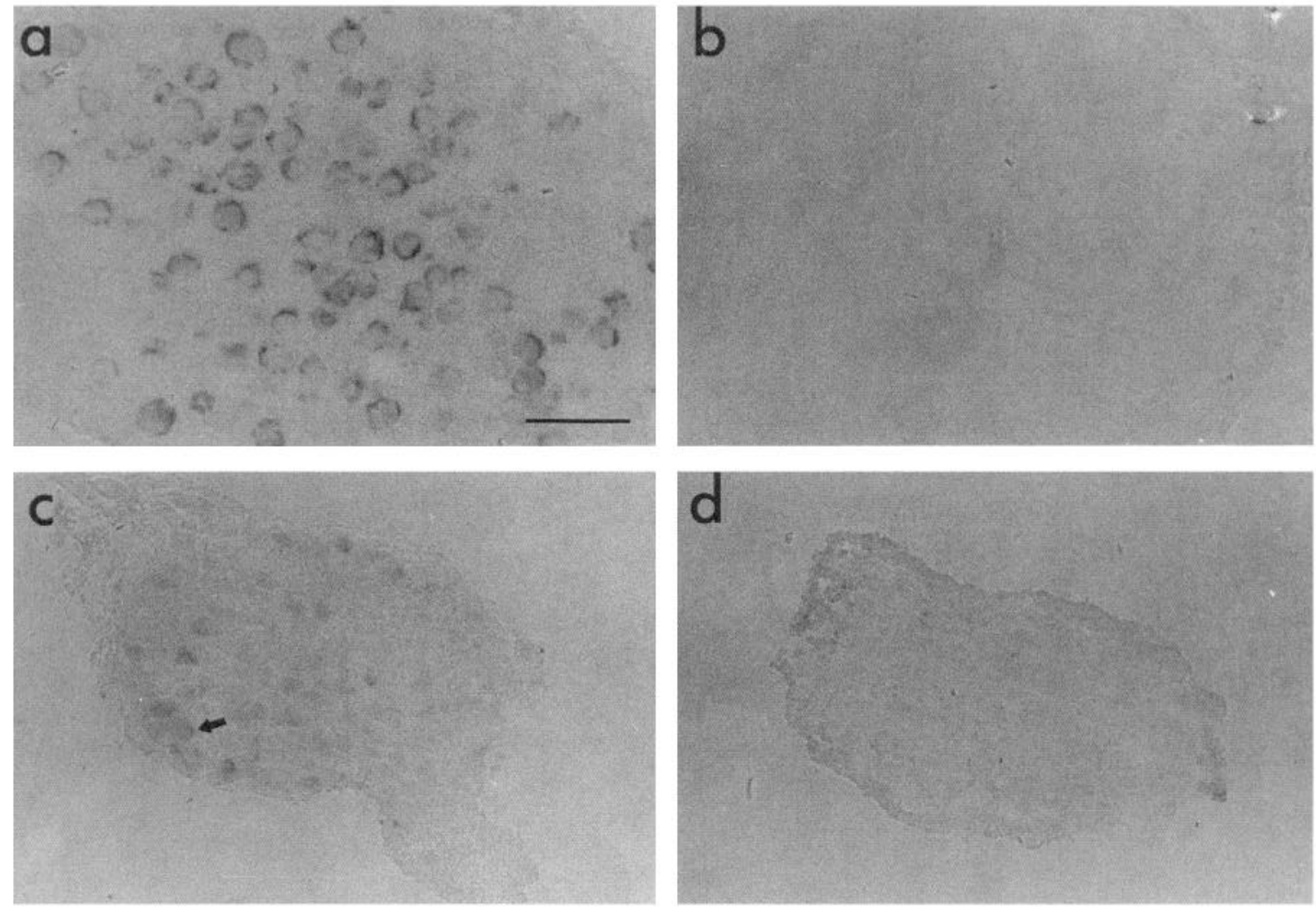

Figure 7. Synaptic vesicle immunoreactivity was reduced by AON ablation. Fixed, permeabilized sections were incubated in a monoclonal antibody to P65 protein; binding was visualized with the PAP technique. $a$, Bright-field photomicrograph of a frozen section from an E18 control ganglion. Large profiles encircling almost every cell body are intensely immunoreactive. $c$, Bright-field photomicrographs of a frozen ciliary ganglion section from an AON-ablated embryo, immunostained for P65 synaptic vesicle protein. Only a few faintly staining profiles are visible (arrow); there are no intense profiles. Reaction product was absent in nonimmune control sections from control $(b)$ and AON-ablated embryos $(d)$. Scale bar, $100 \mu \mathrm{m}$. 

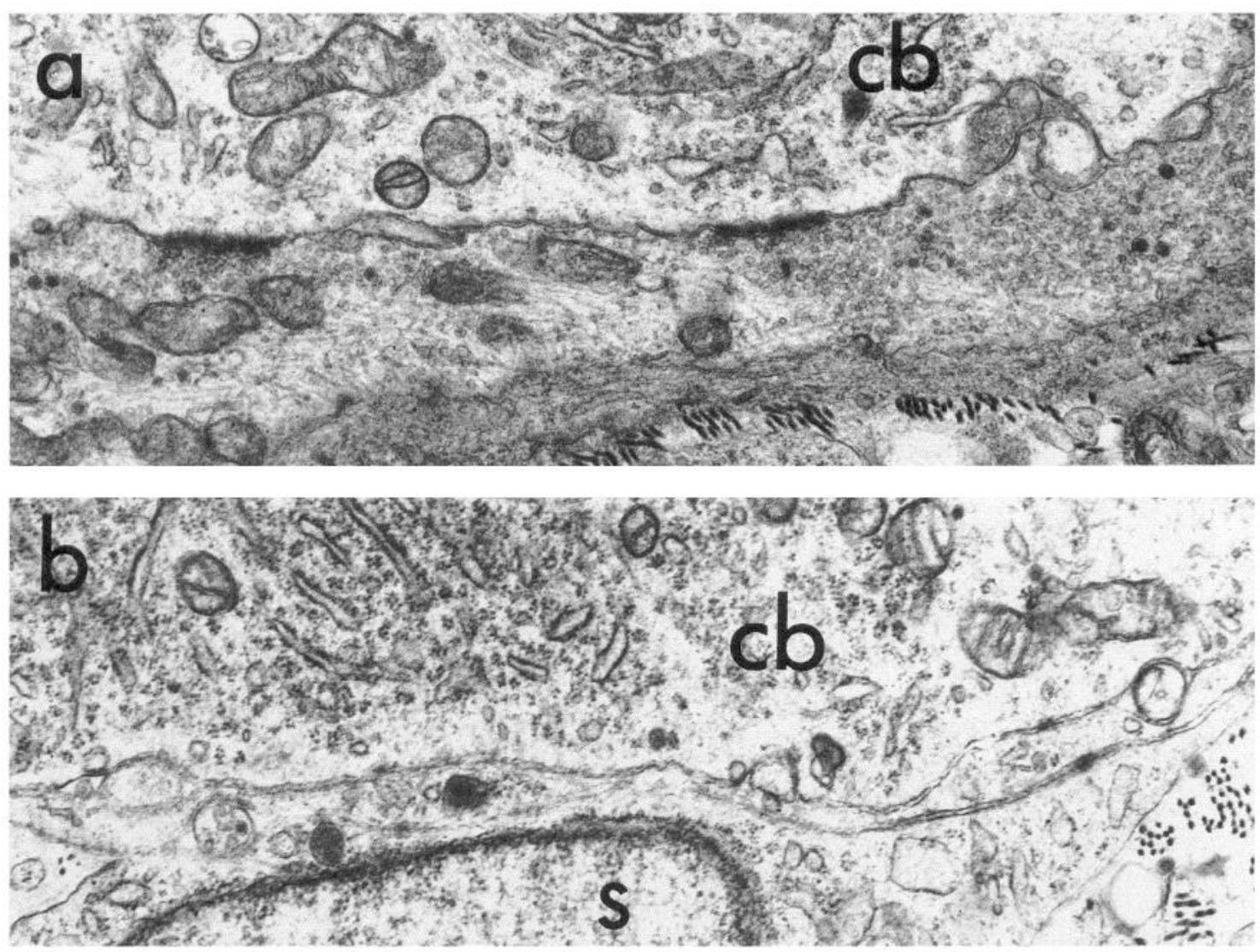

Figure 8. AON ablation eliminated presynaptic terminals and postsynaptic densities. $a$, An electron micrograph of a control ciliary ganglion neuron membrane at E18, 12,000 × magnification. A calciform terminal contains numerous synaptic vesicles and is immediately adjacent to two electron densities in the membrane of the ciliary ganglion cell body $(c b) . b$, An electron micrograph of the membrane of an E18 ciliary ganglion neuron from an AON-ablated embryo, $12,000 \times$ magnification. The neuronal cell $(c b)$ membrane is closely apposed by satellite cell $(s)$ membrane; no synaptic terminal was found anywhere along the membrane of the neuron. The length of membrane shown in $a$ and $b$ is approximately $6 \mu$ m.

those of control ganglia. In three separate experiments, the average yield from E14 AON-ablated ganglia was 826 cells per ganglion. If one assumes that there are 900 cells in each ciliary ganglion following AON ablation on E4 (Furber et al., 1987), at E14 over $90 \%$ of the neurons were recovered. The average yield from age-matched (sham-operated) controls in the same experiments was 1617 cells per ganglion, or, assuming 3000 cells in normal E14 ganglia, only 54\%. The more efficient cell yield from ganglia of AON-ablated embryos may reflect the relative lack of connective tissue in these ganglia compared to controls. At E18, the percentage yield for operated ganglia was $46 \%(414 / 900)$; for controls it was $10 \%(311 / 3000)$. Normal ganglia are surrounded by a firm connective tissue layer at this stage. The yield was not improved by a dissociation in $2 \mathrm{mg} /$ $\mathrm{ml}$ collagenase rather than $0.05 \%$ trypsin. Fewer than 50 cells per ganglion $(<5 \%)$ have been obtained from newly hatched chick ciliary ganglia dissociated with $4 \mathrm{mg} / \mathrm{ml}$ collagenase (McEachern et al., 1989).

It is also unlikely that a subpopulation of cells with reduced sensitivity was selectively lost during the period of cell death. ACh- and GABA-activated currents assayed on E8, prior to the period of cell death, were the same in control and $\mathrm{AON}$-ablated ciliary ganglion neurons (ACh: $575 \pm 255 \mathrm{pA}, N=5$, vs. 608 $\pm 366 \mathrm{pA}, N=5$, for sham-operated controls; GABA: $3869 \pm$ 1548 pA, $N=5$, vs. $2903 \pm 443 \mathrm{pA}, N=5$, for controls).

\section{Efficacy of AON ablation in eliminating synapses}

The apparently normal $\mathrm{ACh}$ - and GABA-activated currents following the prevention of innervation of ciliary ganglion neurons was surprising, considering the known influence of innervation of the accumulation of ACh receptors on skeletal muscle (see Schuetze and Role, 1987, for review) and on sympathetic ganglion neurons in vitro (Role, 1988). One explanation for the lack of effect is that neurons from AON-ablated ganglia were in fact innervated, either because the operation to destroy the AON was only partially successful, or because intraganglionic contacts formed in the absence of innervation from the AON. It was therefore important to determine whether any synapses remained in the ganglion after AON ablation.

Synapses were assayed by immunohistochemistry and electron microscopy. Frozen sections from E18 control and operated ganglia were examined for the presence of immunoreactivity to $\mathrm{mAb}$ P65, a monoclonal antibody against a protein concentrated in synaptic vesicles (Bixby and Reichardt, 1985). mAb P65 binding surrounded most cell bodies in sections from normal, innervated ganglia at E18 (Fig. 7a). No reaction product was evident in sections from control ganglia when the primary antibody was omitted (Fig. $7 b$ ).

Typically six to eight $12 \mu \mathrm{m}$ sections were examined from each ganglion, taken from areas across the entire width of the 

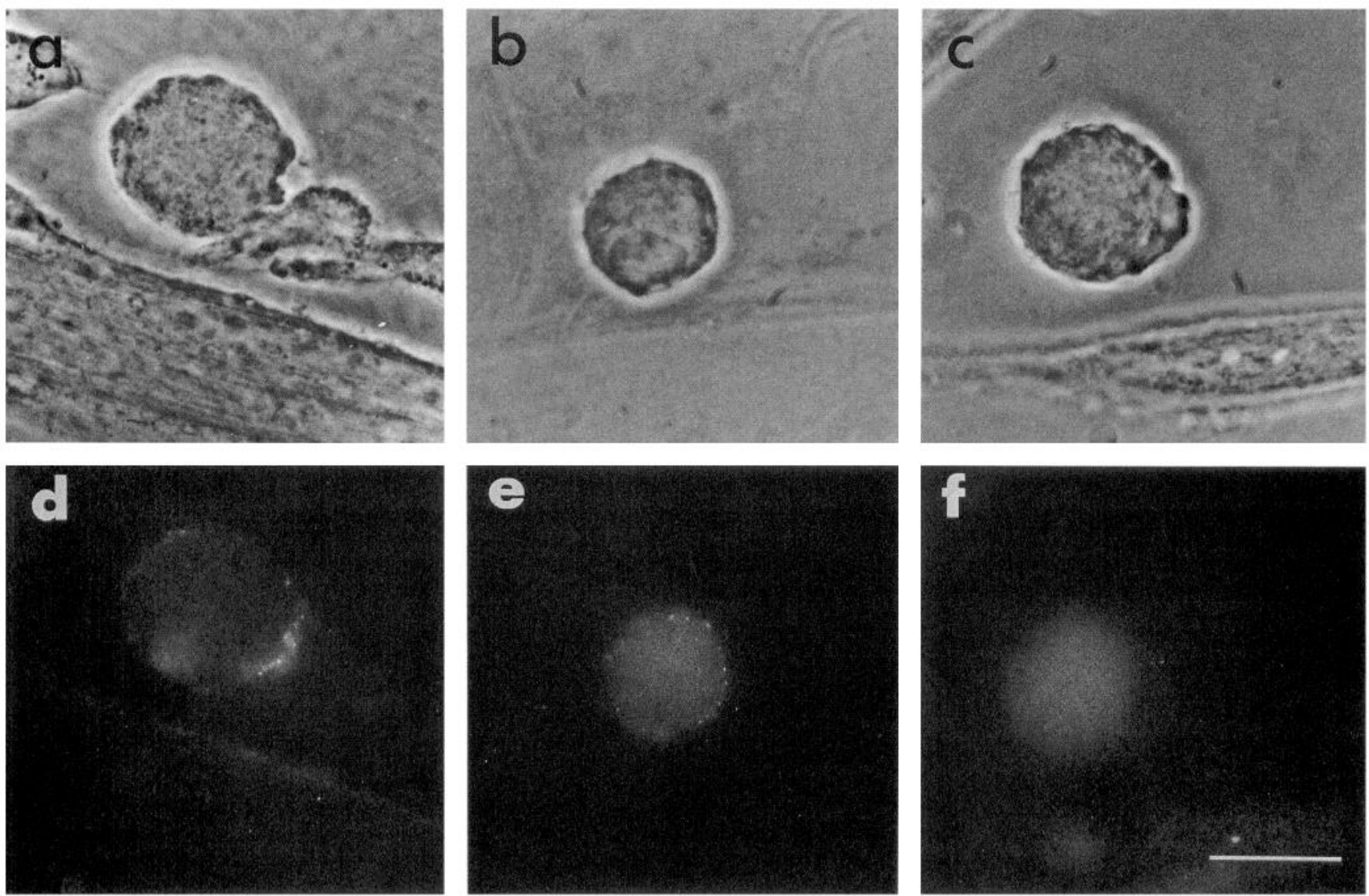

Figure 9. High-density clusters of ACh receptor-like molecules form in the absence of innervation. Acutely dissociated neurons were incubated at $0^{\circ} \mathrm{C}$ in $\mathrm{mAb} 35$, fixed, and incubated in an FITC-secondary, and then a FITC-tertiary antibody for amplification. $a$ and $d$, Phase and fluorescence micrographs, respectively, of an E18 neuron from a control ganglion. mAb35 immunoreactivity was concentrated in small spots ("speckles") on the surface of E14 and E1 8 control neurons. $b$ and $e$, Phase and fluorescence micrographs, respectively, of an E18 neuron from an AON-ablated embryo. Speckles of mAb35 immunoreactivity were also present on the surface of neurons from AON-ablated embryos. Speckles were not seen on neurons when mAb35 was omitted from the first incubation, but the cellular "glow" appeared to be nonspecific $(c, f)$. Scale bar, $10 \mu \mathrm{m}$.

tissue. In $7 / 21(33 \%)$ of the operated ganglia there was no staining at all, and 10/21 (48\%) were faintly stained (a few faint profiles or one dark profile out of all sections examined). Only $4 / 21(19 \%)$ were stained enough to be classified as partially innervated (more than five identifiable profiles out of all the sections examined). We conclude that the synaptic vesicle antigen P65 was markedly reduced in at least $81 \%(17 / 21)$ of operated ganglia at E18. None of the ganglion sections from operated embryos exhibited staining that was comparable to controls. An example of "faint staining" is shown in a section from an operated ganglion in Figure $7 c$; one faint profile is indicated with an arrow. Not unexpectedly, some reaction product was evident within the cytoplasm of cell bodies in operated ganglia. This staining may reflect vesicles destined for exportation to synaptic terminals in the periphery. Cellular staining was abolished in sections from operated ganglia when the primary antibody was omitted (Fig. $7 d$ ).

To rule out the possibility that the decrease in P65 immunoreactivity after AON ablation was simply due to the loss of the antigen from synaptic vesicles, or to a reduction in the number of synaptic vesicles, ganglia were also examined by electron microscopy. In innervated ganglia, the characteristic calyx terminals (de Lorenzo, 1960; Hess, 1965; Landmesser and Pilar, 1972) were easily detected. A typical calyx on a ciliary neuron is shown in Figure $8 a$. The terminal is filled with clear synaptic vesicles and is apposed by two postsynaptic densities, presumably specialized synaptic sites (de Lorenzo, 1960; Jacob et al., 1984). Such postsynaptic densities numbered between 815 per cell profile. One E18 control ganglion was sectioned; no bouton-like terminals were observed in the 16 sections examined. At E18, the ciliary and choroid populations are segregated, with the ciliary cells in the dorsolateral half and the choroid cells in the ventromedial half (Hess, 1965; Pilar et al., 1980; Epstein et al., 1988). Presumably, our sections sampled the region of the ganglion containing only ciliar cells.

Five AON-ablated ganglia were examined. Four of the five ganglia differed dramatically from controls; no calyces were observed. An example of a naked cell profile is shown in Figure $8 b$; the neuron (cb, cell body) membrane is immediately adjacent to a satellite cell (s). Out of more than 50 cell profiles examined, only two boutons were found on one cell profile. The source of these rare boutons could have been either the $\mathrm{AON}$, or other ganglionic neurons. In either case, the amount of synaptic contact was drastically reduced by AON ablation in four out of five ganglia.

One of the five ganglia from an operated embryo was apparently not denervated; every cell perimeter examined in $10 \mathrm{sec}-$ tions from this ganglion was surrounded by a calyx containing 

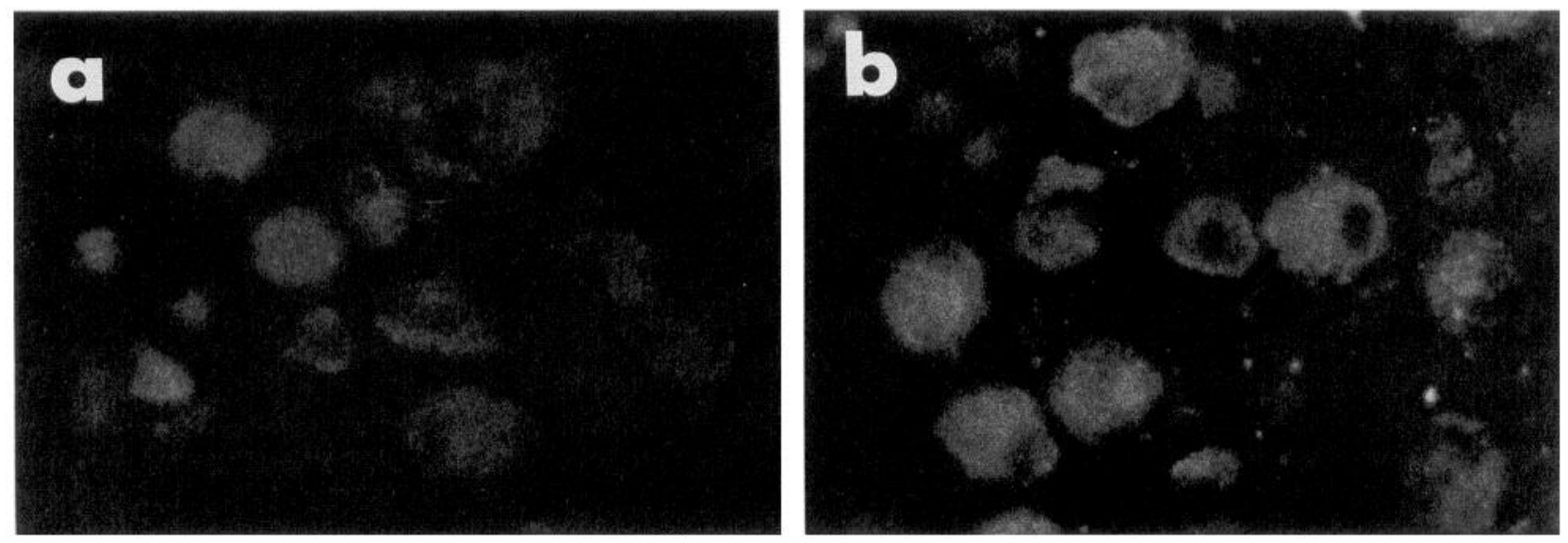

Figure 10. ACh receptor-like molecules were present in cell bodies in frozen sections of both control and operated ciliary ganglia at E18. Freshly dissected ganglia were frozen and sectioned at $16 \mu \mathrm{m}$ intervals. Sections were treated in the same manner as acutely dissociated neurons. Cell profiles were uniformly immunoreactive in ganglia from control embryos $(a)$ and AON-ablated embryos $(b)$.

numerous synaptic vesicles. The dramatic reduction in synaptic vesicle antigen in $80 \%$ of the operated ganglia (cf. Fig. $7 c, d$ ) most likely corresponds to a reduction in presynaptic terminals, since the same percentage of success was observed with both immunohistochemistry and electron microscopy.

\section{ACh receptor distribution}

In innervated ciliary ganglia, clusters of $\mathrm{ACh}$ receptors are found beneath presynaptic terminals in the late embryonic and posthatching chick ciliary ganglion (Jacob et al., 1984, 1986; Loring and Zigmond, 1987; Jacob and Berg, 1988). In fact, as soon as synapses can be recognized ultrastructurally (E4.5), ACh receptors (detected by the binding of $\mathrm{mAb} 35$ ) are found concentrated at such sites (Jacob, 1991). In order to achieve the close association between receptors and nerve terminals, preganglionic nerve terminals from the AON may cluster existing receptors, rather than inducing receptors beneath points of synaptic contacts (see Sargent and Pang, 1988).

Using a triple-sandwich immunofluorescence technique (see Materials and Methods), we detected ACh receptor clusters on freshly dissociated E14 and E18 chick ciliary ganglion neurons. The clusters appeared as small $(<1 \mu \mathrm{m})$, bright spots ("speckles") at both E14 (not shown) and E18 (Fig. 9a,d). The region in the lower left quadrant of the cell that is slightly brighter than the surrounding area is actually a group of speckles in a slightly different focal plane. The speckles varied at most twofold in diameter. Usually, several groupings, or aggregates, of speckles were evident on the cell surface, but they were not restricted to one pole of the cell. It seems likely that such aggregates of mAb35 speckles reflect the persistence of postsynaptic sites after enzymatic dissociation.

Speckles were also observed on neurons from E18 AONablated embryos (Fig. 9b,e). In the focal plane illustrated, the speckles appear to be evenly distributed around the cell perimeter. Speckling was observed in more than 30 cells from operated embryos, in two separate experiments. The speckles on uninnervated neurons appeared to be slightly smaller than speckles on control neurons, and they were not as obviously grouped into larger aggregates. However, these differences were not quantitated.

The protocol used with dissociated neurons ensured that only receptors on the cell surface were labeled. Intracellular mAb35 binding sites were examined in frozen sections of control and AON-ablated ganglia. The level of mAb35 immunofluorescence was not decreased in AON-ablated ganglia compared to controls (Fig. 10). Cell body immunoreactivity was absent from sections that were not incubated in mAb35 before the addition of secondary and tertiary antibodies (not shown). We found it important to examine fresh, frozen sections. Immunofluorescence was remarkably reduced when sections were fixed in $10 \%$ formaldehyde prior to the addition of mAb35 (not shown).

\section{Discussion}

The sevenfold increase in ACh-activated current that occurs in embryonic chick ciliary ganglion neurons between E6 and E18 does not depend on continued cholinergic innervation from the AON. Likewise, the increase in GABA-activated current between E6 and E14 and the subsequent decline between E14 and E18 does not depend on continued AON input. In previous experiments, we found that extirpation of the eye on E2 did not prevent the developmental increase in ACh-activated currents (Engisch and Fischbach, 1990). The AON degenerates several days after early eye removal (Cowan and Wenger, 1968), so after a transient period of innervation, the ganglia are deprived of both the eye and the AON by E14. The results reported here demonstrate that $\mathrm{ACh}$-activated current increases on schedule even when the ganglion neurons are deprived of innervation from E4.

The high ACh sensitivity of neurons from AON-ablated embryos cannot be due to innervation of the ciliary ganglion neurons by a few remaining preganglionic terminals or by neighboring neurons within the ganglion. Light and electron microscopic examination revealed that synaptic contacts were virtually absent in all but one of the ganglia examined from operated embryos. The efficacy of early AON ablation in preventing synapse formation was also documented in a previous study of chick embryos (Furber et al., 1987). Moreover, few synaptic contacts are evident in ganglia that are denervated in the immediate posthatching period (Jacob and Berg, 1987, 1988). In this regard, the chick ciliary ganglion appears to be different from two other parasympathetic ganglia, the rabbit ciliary ganglion (Johnson, 1988) and frog cardiac ganglion (Sargent and Dennis, 1977, 1981), where intraganglionic connections have been detected electrophysiologically after preganglionic nerve 
transection in adult animals. It is possible functional connections formed between ciliary ganglion neurons after AON ablation that did not have any of the normal ultrastructural features of synapses.

It is unlikely that a subpopulation of insensitive neurons was selectively lost during the period of programmed cell death that occurs between E9 and E1 4 (Landmesser and Pilar, 1974). AONdeprived neurons have normal $\mathrm{ACh}$ responses as late as E8. It is also unlikely that a selective loss of insensitive cells occurs during the dissociation procedure since percentage cell yields were greater for ganglia from operated embryos than for control ganglia.

Our results are consistent with the observation that denervation of ciliary ganglion neurons at $1 \mathrm{~d}$ posthatching has no effect on ACh sensitivity (McEachern et al., 1989) or on surface mAb35 binding (Jacob and Berg, 1988; McEachern et al., 1989) measured $10 \mathrm{~d}$ later. On the other hand, there is a threefold reduction in $\mathrm{mAb} 35$ binding to posthatching denervated ganglion homogenates that appears to be due to a loss of intracellular binding sites (Jacob and Berg, 1987, 1988; McEachern et al., 1989). We did not find a reduction in cytoplasmic $\mathrm{mAb} 35$ binding on E1 8 after AON ablation on E4. In recent experiments, a decrease in intracellular binding sites has been observed in embryonic ganglia following early AON ablation (M. Jacob, personal communication). This effect appears to be transient with a return toward control levels by E12.

We expected that a period of innervation would be essential for the developmental upregulation of $\mathrm{ACh}$ receptors on embryonic ciliary ganglion neurons. Our thinking was influenced by studies of neuromuscular junction formation. In chick motoneuron/myotube cell cultures, there is a marked increase in the number of ACh receptors at newly formed nerve-muscle synapses (Frank and Fischbach, 1979; Role et al., 1985; Dubinsky et al., 1989). The nerve-induced receptor clusters extend beyond the immediate neurite-muscle contact. In addition to perisynaptic receptor clusters, a general increase in the number of $\mathrm{ACh}$ receptors on myotubes located near intact spinal cord explants suggests a diffusible $\mathrm{ACh}$ receptor inducing factor (Cohen and Fischbach, 1977). In an experiment that parallels the present study, removal of the neural tube in young chick embryos resulted in formation of fewer than $5 \%$ of the normal number of $\mathrm{ACh}$ receptor clusters in "aneural" limbs on E10 (Fallon and Gelfman, 1989). Also, it has been known for some time that denervation of immature neuromuscular junctions causes ACh receptor clusters to rapidly disappear in vivo (Slater, 1982) and in culture (Kuromi and Kidokoro, 1984).

Perhaps more relevant to the studies reported here are recent observations that presynaptic neurons regulate the chemosensitivity of embryonic motoneurons and sympathetic ganglion neurons in vitro. Embryonic spinal cord motoneurons are more sensitive to glutamate when cultured with interneurons than when sorted from other cell types and maintained in vitro as a pure population (O'Brien and Fischbach, 1986). Similarly, AChactivated current increases severalfold when dissociated embryonic chick sympathetic ganglion neurons are cocultured with explants from the dorsal spinal cord, a source of cholinergic preganglionic neurons (Role, 1988). In this case, contact with presynaptic terminals was not essential, as the ACh sensitivity of sympathetic ganglion neurons was also increased in the presence of neurally conditioned medium (Role, 1988; Gardette et al., in press). Moreover, ventral spinal cord explants containing cholinergic motoneurons can substitute for dorsal spinal cord explants in increasing ACh sensitivity of sympathetic ganglion neurons in vitro, even though the ganglion neurons are not innervated by motoneurons in vivo (Gardette et al., in press).

In discussing whole-cell ACh-activated currents, we have tacitly assumed that each ciliary ganglion neuron is a synaptic target. This seems reasonable considering that presynaptic terminals exert an influence beyond the immediate contact in skeletal muscle and in other types of neurons. However, it is possible that the effect of AON nerve terminals is extremely focal from the start, and that synaptic and extrasynaptic receptors should be considered separately (see Jacob et al., 1984, 1986; Loring and Zigmond, 1987; Jacob and Berg, 1988). For example, an increase in extrasynaptic sensitivity of uninnervated neurons could have obscured a reduction in the number of synaptic receptors. One must then assume that the identical $\mathrm{ACh}$ sensitivities of innervated and never-innervated neurons on E1 8 is a coincidence, and this seems unlikcly.

On a qualitative level, the number and intensity of $\mathrm{ACh}$ receptor clusters identified by fluorescence immunohistochemistry were not different on uninnervated neurons, although the clusters did appear to be more evenly distributed on the cell surface. Jacob and Berg (1988) did not detect changes in ACh receptor clusters on posthatching denervated ciliary ganglion neurons at the electron microscopic level after labeling receptors with HRP-mAb35 conjugates. More quantitative estimates of the number of clustered receptors and of the density and total number of extrasynaptic (extracluster) ACh receptors are needed. We believe that the fluorescence images reflect the true distribution of $\mathrm{ACh}$ receptors because incubation in mAb35 was carried out on ice (the cells were fixed prior to addition of secondary and tertiary antibodies), a temperature at which antibody-induced patching should be greatly inhibited (Schreiner and Unanue, 1976; Storrie and Edelson, 1977; Friedlander and Fischman, 1979). However, Conti-Tronconi et al. (1981) have observed an increase in the sedimentation rate of $A C h$ receptors incubated with mAb35. Further experiments with Fab fragments would resolve this issue.

We cannot rule out the possibility that a transient interaction with AON terminals, between E3.5 and E4, or perhaps even during the migration of ganglionic precursor cells, is sufficient to trigger the entire developmental program of increases in $\mathrm{ACh}$ and GABA scnsitivity. Recently, Brenner et al. (1990) reported that mRNA for the $\epsilon$-subunit of the $\mathrm{ACh}$ receptor appears at the neuromuscular junction of rat soleus muscle $5 \mathrm{~d}$ after birth and continues to accumulate at the junction up to postnatal day 12 , even when the muscle is denervated at birth. They suggested that interaction with the presynaptic terminal between E17 and birth "imprinted" the junction with the signals necessary to induce $\epsilon$-subunit mRNA expression.

The simplest interpretation of our results is that the expression of functional ACh receptors on ciliary ganglion neurons during embryonic development is regulated by factors within the ganglion itself. If an intrinsic clock is at work, then it must depend on a permissive local environment because the ACh sensitivity of embryonic chick ciliary ganglion neurons decreases rather than increases in dissociated cell culture (Crean et al., 1982; Margiotta and Berg, 1982; Engisch and Fischbach, 1990), even though the neurons innervate one another in this situation (Margiotta and Berg, 1982). Target-derived factors added to the culture medium do increase the ACh sensitivity of the neurons (Smith et al., 1983; Halvorsen et al., 1991) as do cocultured skeletal myotubes (Crean et al., 1982; Margiotta and Berg, 1982; 
Tuttle, 1983), but the peak ACh-activated current remains much smaller than ACh responses of neurons in vivo (acutely dissociated neurons; Margiotta and Gurantz, 1989; Engisch and Fischbach, 1990).

Chick ciliary ganglion neurons promote the accumulation of ACh receptors on cultured embryonic myotubes (Margiotta and Berg, 1982; Role et al., 1985, 1987). If the same factor that induces $\mathrm{ACh}$ receptor cluster formation in the periphery, or a related one, is released from ganglion cell bodies it might regulate receptor expression in neighboring neurons. Experiments are under way to examine $\mathrm{ACh}$ sensitivity of ciliary ganglion neurons in high-density cell culture and in organotypic explant culture established from different stage embryos.

\section{References}

Bixby JL, Reichardt LF (1985) The expression and localization of synaptic vesicle antigens at neuromuscular junctions in vitro. J Neurosci 5:3070-3080.

Brenner HR, Witzemann V, Sakmann B (1990) Imprinting of acetylcholine receptor messenger RNA accumulation in mammalian neuromuscular synapses. Nature 344:544-547.

Choi DW, Fischbach GD (1981) GABA conductance of chick spinal cord and dorsal root ganglion neurons in cell culture. J Neurophysiol 45:605-643.

Cohen SA, Fischbach GD (1977) Clusters of acetylcholine receptors located at identified nerve-muscle synapses in vitro. Dev Biol 59:2438.

Conti-Tronconi B, Tzartos S, Lindstrom J (1981) Monoclonal antibodies as probes of acetylcholine receptor structure. 2 . Binding to native receptor. Biochemistry 20:2181-2191.

Cowan WM, Wenger E (1968) Degeneration of the nucleus of origin of the preganglionic fibers to the chick ciliary ganglion following early removal of the optic vesicle. J Exp Zool 168:105-124.

Crean G, Pilar G, Tuttle JB, Vaca K (1982) Enhanced chemosensitivity of chick parasympathetic neurons in co-culture with myotubes. $J$ Physiol (Lond) 331:87-104.

de Lorenzo AJ (1960) The fine structure of synapses in the ciliary ganglion of the chick. J Biophys Biochem Cytol 7:31-36.

Dubinsky JM, Loftus DJ, Fischbach GD, Elson EL (1989) Formation of acetylcholine receptor clusters in chick myotubes: migration or new insertion? J Cell Biol 109:1733-1743.

Engisch KL, Fischbach GD (1990) The development of ACh- and GABA-activated currents in normal and target-deprived embryonic chick ciliary ganglia. Dev Biol 139:417-426.

Epstein ML, Davis JP, Gellman LE, Lamb JR, Dahl JL (1988) Cholinergic neurons of the chicken ciliary ganglion contain somatostatin. Neuroscience 25:1053-1060.

Fallon JR, Gelfman CE (1989) Agrin-related molecules are concentrated at acetylcholine receptor clusters in normal and aneural developing muscle. J Cell Biol 108:1527-1535.

Frank E, Fischbach GD (1979) Early events in neuromuscular junction formation in vitro. J Cell Biol 83:143-158.

Friedlander M, Fischman DA (1979) Immunological studies of the embryonic muscle cell surface. J Cell Biol 81:193-214.

Furber S, Oppenheim RW, Prevette D (1987) Naturally-occurring neuron death in the ciliary ganglion of the chick embryo following removal of preganglionic input: evidence for the role of afferents in ganglion cell survival. J Neurosci 7:1816-1832.

Gardette R, Listerud MD, Brussaard B, Role LW (1991) Developmental changes in transmitter sensitivity and synaptic transmission in embryonic chicken sympathetic neurons innervated in vitro. Dev Biol 147:83-95.

Halvorsen SW, Schmid HA, McEachern AE, Berg DK (1991) Regulation of acetylcholine receptors on chick ciliary ganglion neurons by components from the synaptic target tissue. J Neurosci 11:2177-2186.

Hamill OP, Marty A, Neher E, Sakmann B, Sigworth FJ (1981) Improved patch-clamp techniques for high-resolution current recordings from cells and cell-free membrane patches. Pfluegers Arch 391:85100.

Hess A (1965) Developmental changes in the structure of the synapse on the myelinated cell bodies of the chicken ciliary ganglion. J Cell Biol 25:1-19.

Jacob M (1991) Acetylcholine receptor expression in developing chick ciliary ganglion neurons. J Neurosci 11:1701-1712.

Jacob MH, Berg DK (1983) The ultrastructural localization of $\alpha$-bungarotoxin binding sites in relation to synapses on chick ciliary ganglion neurons. J Neurosci 3:260-271.

Jacob MH, Berg DK (1987) Effects of preganglionic denervation and postganglionic axotomy on acetylcholine receptors in the chick ciliary ganglion. J Cell Biol 105:1847-1854

Jacob MH, Berg DK (1988) The distribution of acetylcholine receptors in chick ciliary ganglion neurons following disruption of ganglionic connections. J Neurosci 8:3838-3849.

Jacob MH, Berg DK, Lindstrom JM (1984) Shared antigenic determinant between the Electrophorus acetylcholine receptor and a synaptic component on chicken ciliary ganglion neurons. Proc Natl Acad Sci USA 81:3223-3227.

Jacob MH, Lindstrom JM, Berg DK (1986) Surface and intracellular distribution of a putative neuronal nicotinic acetylcholine receptor. J Cell Biol 103:205-214.

Johnson DA (1988) Regulation of intraganglionic synapses among rabbit parasympathetic neurones. J Physiol (Lond) 397:51-62.

Kuromi H, Kidokoro Y (1984) Denervation disperses acetylcholine receptor clusters at the neuromuscular junction in Xenopus cultures. Dev Biol 104:421-427.

Landmesser L, Pilar G (1972) The onset and development of transmission in the chick ciliary ganglion. J Physiol (Lond) 222:69 I-713.

Landmesser L, Pilar G (1974) Synaptic transmission and cell death during normal ganglionic development. J Physiol (Lond) 241:737749 .

Lansdorp PM, van der Kwast TH, de Boer M, Zeijlemaker WP (1984) Stepwise amplified immunoperoxidase (PAP) staining. I. Cellular morphology in relation to membrane markers. $J$ Histochem Cytochem 32:172-178.

Loring RH, Zigmond RE (1987) Ultrastructural distribution of [ $\left.{ }^{125} \mathrm{I}\right]$ toxin $\mathrm{F}$ binding sites on chick ciliary ganglion neurons: synaptic localization of a toxin that blocks ganglionic nicotinic receptors. $J$ Neurosci 7:2153-2162.

Loring RH, Dahm LM, Zigmond RE (1985) Localization of $\alpha$-bungarotoxin binding sites in the ciliary ganglion of the embryonic chick: an autoradiographic study at the electron microscopic level. Neuroscience 14:645-660.

Margiotta JF, Berg DK (1982) Functional synapses are established between ciliary ganglion neurons in dissociated cell culture. Nature 296:152-154.

Margiotta JF, Gurantz. D (1989) Changes in the number, function, and regulation of nicotinic acetylcholine receptors during neuronal development. Dev Biol 135:326-339.

McEachern AE, Jacob MH, Berg DK (1989) Differential effects of nerve transection on the $\mathrm{ACh}$ and GABA receptors of chick ciliary ganglion neurons. J Neurosci 9:3899-3907.

Narayanan CH, Narayanan Y (1976) An experimental inquiry into the central source of preganglionic fibers to the chick ciliary ganglion. J Comp Neurol 166:101-110.

O'Brien RJ, Fischbach GD (1986) Modulation of embryonic chick motoneuron glutamate sensitivity by interneurons and agonists. $J$ Neurosci 6:3290-3296.

Pilar G, Landmesser L, Burstein L (1980) Competition for survival among developing ciliary ganglion cells. J Neurophysiol 43:233-254.

Role LW (1988) Neural regulation of acetylcholine sensitivity in embryonic sympathetic neurons. Proc Natl Acad Sci USA 85:28252829.

Role LW, Fischbach GD (1987) Changes in the number of chick ciliary ganglion neuron processes with time in cell culture. J Cell Biol 104: 363-370.

Role LW, Matossian VR, O'Brien RJ, Fischbach GD (1985) On the mechanism of acetylcholine receptor accumulation at newly formed synapses on chick myotubes. J Neurosci 5:2197-2204.

Role LW, Roufa DG, Fischbach GD (1987) The distribution of ACh receptor clusters and sites of transmitter release along chick ciliary ganglion neurite-myotube contacts in culture. J Cell Biol 104:371379.

Sargent PB, Dennis MJ (1977) Formation of synapses between parasympathetic neurones deprived of preganglionic innervation. Nature 268:456-458.

Sargent PB, Dennis MJ (1981) The influence of normal innervation 
upon abnormal synaptic connections between frog parasympathetic neurons. Dev Biol 81:65-73.

Sargent PB, Pang DZ (1988) Denervation alters the size, number, and distribution of clusters of acetylcholine receptor-like molecules on frog cardiac ganglion neurons. Neuron 1:877-886.

Schreiner GF, Unanue ER (1976) Membrane and cytoplasmic changes in B lymphocytes induced by ligand-surface immunoglobulin interaction. Adv Immunol 24:37-165.

Schuetze SM, Role LW (1987) Developmental regulation of nicotinic acetylcholine receptors. Annu Rev Neurosci 10:403-457.

Slater CR (1982) Neural influence on the postnatal changes in ace- tylcholine receptor distribution at nerve-muscle junctions in the mouse. Dev Biol 94:23-30.

Smith MA, Margiotta JF, Berg DK (1983) Differential regulation of acetylcholine sensitivity and $\alpha$-bungarotoxin-binding sites on ciliary ganglion neurons in cell culture. J Neurosci 3:2395-2402.

Storrie B, Edelson PJ (1977) Distribution of concanavalin A in fibroblasts: direct endocytosis versus surface capping. Cell 11:707-717.

Tuttle JB (1983) Interactions with membrane remnants of target myotubes maintains transmitter sensitivity of cultured neurons. Science 220:977-979. 